\title{
The Relationship Between Volatility and Predictability of Profit
}

\author{
Yadollah Dakka ${ }^{1}$, Malihe Rostami ${ }^{2}$ \\ ${ }^{1}$ Department of management, Firoozkooh Branch, Islamic Azad University, Tehran, Iran \\ ${ }^{2}$ Department of finance and accounting, Electronic Branch, Islamic Azad University, Tehran, Iran
}

Email address:

daka.reza@yahoo.com(Y. Daka),mle_rostami@yahoo.com (M. Rostami)

\section{To cite this article:}

Yadollah Dakka, Malihe Rostami. The Relationship Between Volatility and Predictability of Profit. Journal of Finance and Accounting. Vol. 3, No. 4, 2015, pp. 69-76. doi: 10.11648/j.jfa.20150304.12

\begin{abstract}
This article is discussed relationship between volatility and predictability of profit. This is clear that one purposes of accounting and preparing financial statements, provide useful information to facilitate decision-making. With financial reports is done predictability for organization's performance future. Accounting profit forecasts as a factor in economic decision-making are a favorite of investors, creditors, managers, financial analysts, and researchers. People can use this information in evaluation models, to improve the efficiency of capital markets, to assess their ability to pay, risk assessment, assessment of economic performance and stewardship of management, evaluation of how management accounting methods used in the discussion of income smoothing earnings forecasts for management decisions and use the economic, finance and accounting research. In this study to review and analyze the relationship between volatility and the ability to forecast profits in the short term and long term in an Iranian bank, in the period of 2009 till 2014. In fact, this article seeks to improve profit forecasts by variability of profits. The results show that the volatility of short-term and long-term profitability and predictability are inversely. The relationship between predictability and volatility is weaker than the relationship between predictability and the level of profits in the short-term and long-term. So, the current profit more appropriate tool to judge the predictability of earnings. Long-term and short-term profit trends mean reversion.
\end{abstract}

Keywords: Profit, Volatility, Predictability, Long-Term and Short-Term

\section{Introduction}

Profit is one of important issue in financial statement that can attract the user's attention of financial statements. Investors, creditors, directors, employees, analysts, governments and other users of financial statements use profit as a basis for making investment decisions, lending, policy interest payments, evaluating, the calculation of taxes and other decisions. Information provided by the organization, based on past events but, users of financial statements need information about the organization's future to decide [1]

The forecasting profit by the management can provide information for the future. Therefore, since the profit is important, managers are required to use it to forecast profits. Several tools and resources for managers are to increase forecast accuracy. Source and tools will be safer that will lead to a lower error rate and to be closer to reality $[1,2]$

The effect of organization's current profit is the base of future profits. So, this is necessary to improve the way and tools of prediction in profits field.

Therefore, in this study the effects of profit volatility as a process and also profit behavior on relationship between current profits against future profits in the short and long-term earnings are expected to improve profit.

\section{Research Theory}

Accounting profit is an index measuring the activity of an economic entity. The importance of profit is the subject of the development of management quantitative techniques and the necessity of user's attention to financial statements that with the passage of restrictive measures in view of the result of past activities help users to decision-making and behave differently. Profit is a tool to evaluate organization's performance and also, it is a way to predict future [3,4].

The importance of the decision for the benefit of investors, 
have realized the benefits of interest in decision-making [1]. In the past decade due, according to economic conditions and the expansion of investment institutions, investors attach great importance to the preservation of capital and profits, or increase capital reserves and all views based on scientific methods to analyze and assess the future profitability of shares The problem is that an investor who purchased a share and at what time?

The price is still very important and perhaps the most important factor in the purchase of common stock. In fact, economic fluctuations, as well as a wide range of prices change. Therefore, an investor should always consider the question whether, regardless of the quality and intrinsic value based on realistic assessment of interest payments and other factors that affect the purchase of securities, do not pay a high price [3].

Many investors consider in their forecasts, factors such as return on equity and price-to-earnings $(\mathrm{P} / \mathrm{E})$ ratio. Another important factor in considering the future could be stock options and given that the past performance and current business can be carefully studied. This analysis should be used as the basis for predicting the future and predict important factors that affect the future prospects be considered [2].

The purpose accounting is collecting and interpreting financial information to a proper manual operation for use by management, investors and other interested parties to provide. Also, users need financial reports to predict future and decide now to invest or not. It should be noted that the distance between the projections and decisions. Evaluate profitability need to focus on anticipated loss is probably requires consideration in terms of prediction error occurs which in turn requires knowledge of other variables in the model of decision-making there [3].

\subsection{Profit Forecast by Management}

Profit is major financial statement items that attracted the attention of the users of the financial statements. Investors, creditors, directors, employees, analysts, governments and other users of financial statements of profit use as a basis for making investment decisions, lending, policy interest payments, evaluating, the calculation of taxes and other decisions $[6,3]$.

Information provided by the organization and therefore profits, based on past events, but investors who need information about the future of the organization. One of the ideas in this case, providing historical and current information by business unit is the only way that investors can make their predictions for the future. Another approach is to manage the resources having to do reliable predictions, and to the public release of these forecasts, we increase the efficiency of financial markets [1].

\subsection{Affecting Factors on Forecast Accuracy of Management Profit}

The disclosure of information for market, impacts accurately predict revenue. Organizations that emit more data for external users have accurately predicted more profit. There are theories that suggest that the capital structure to accurately predict the impact of profit-leaves. It may also be in accordance with the interests of managers and owners. Because administrators may be looking for their own interests and hidden part of the information from owners and investors are not effective [7]

Factors affect the accuracy of the forecasts of corporate profits, some of which are as follows:

- Organization's size

- Financial leverage

- Forecast horizon

- Organization life

- Profit changes [8]

\subsection{The Importance of the Profit Forecast}

Profit forecast as the actual profit organization is critical. The current value of an organization and the value of a share of the expected future distributions will depend on the will of the organization to the shareholders. A current or potential shareholders, based on the expectations with regard to maintenance, the sale or purchase of shares will be decided. Thus, expectations about the future distribution of these investment decisions are primarily important. If the reported profit and pay dividends relationship exists, the investors focus on expect about future $[9,4]$.

Given the above it can be concluded that the profit anticipated being useful in the following cases:

- help to assess the profitability of business units

- The current value of the shares or the value of the organization

- Estimation of investment risk in business

- risk assessment concessional lending to business [3]

\subsection{Profit Forecast Error}

Sometimes investors cannot communicate directly with the organizations and also, in the absence of the financial analysts are forced to rely on published information. The financial information contained in the report is profit forecasting to sell shares that are required to provide, The profit forecasts made (by managers or others) and its authenticity is one of the ways to reduce the information asymmetry between the major shareholders and potential investors. Financial statements and profit announcing is important and effective in stock market information and anticipated earnings per share if has special content, it can affect the behavior of users to the actual and potential shareholders and also make increase and decrease of the price and trading volume $[9,10,11]$.

Since the announcement of profit estimate an effective factor in investors' decisions to buy, sell or hold the stock, the expected earnings per share of at least deviation from the actual amount are available [2].

\subsection{Mean Reversion Phenomenon}

Since in the present study the phenomenon of mean reversion is mentioned in detail in the phenomenon of mean 
reversion in stock prices and profits are mentioned.

\subsubsection{Mean Reversion in Stock Prices}

According to the efficient market hypothesis, share prices react quickly to new information. Random walk process, the market believes that the stock returns cannot be predicted based on past changes. But providing evidence of a disorder such as a return to the average price of shares and the continuation of prices, the efficient market hypothesis is faced with doubts. Price movements in the stock market tend to neutralize each other long term monthly and yearly. This behavior is called mean reversion $[10,12]$.

The phenomenon of mean reversion is a branch of questionable behavioral finance. Mean reversion shows response and continuing excessive prices, the inefficiency or possibly irrational pricing in the stock market. Supporters of mean reversion believe that the response was too short and arbitrage opportunities in the equity markets, the average price during the period subsequent return. Approbation or disapproval of mean reversion phenomenon it is important because this phenomenon in a market make some useful models for most of the market's return. In addition confirm the presence of mean reversion in stock prices in a market is indicative of inefficiency market $[13,14,3]$

\subsubsection{Mean Reversion in Profit}

Profit of behavior follows behavior mean reversion or fixes expectations. There is mean reversion of profit, evaluation and profit forecasts are very important. The phenomenon of mean reversion discusses profit in short term and long term. High and low income (loss) tends to have mean reversion. They added that there are profits at all levels of mean reversion but the amount of that is different $[10,13,15]$

\section{Prior Studies}

In table 1 some important studies in profit and earning fields are shown.

Table 1. Prior studies in profit and earning field.

\begin{tabular}{|c|c|c|c|}
\hline Author & year & Subject & Result \\
\hline Haghighat, H., Mo’tamed, M. [15] & 2012 & Relationship between profit and forecast volatility & $\begin{array}{l}\text { This research is discussed the effects of profit } \\
\text { position on fluctuations and changes. }\end{array}$ \\
\hline Mehrani, S., Hesarzade, R. [3] & 2012 & Fluctuations in its earnings forecasts & $\begin{array}{l}\text { This article is done to find some important results on } \\
\text { anticipated profit and volatility }\end{array}$ \\
\hline Taghavi, M. Janani, M.H. [1] & 2010 & Tehran Stock Exchange and macroeconomic variables & $\begin{array}{l}\text { This study is focussed on macroeconomic variables } \\
\text { specially revenues }\end{array}$ \\
\hline Dichev, I. D. and Tang, V. W. [14] & 2009 & $\begin{array}{l}\text { Matching and the changing properties of accounting } \\
\text { earnings over the last } 40 \text { years }\end{array}$ & $\begin{array}{l}\text { This research is discussed about and the changing } \\
\text { properties of accounting earnings }\end{array}$ \\
\hline Dichev, I. and Tang, V. W. [13] & 2009 & Earnings volatility and earnings predictability & $\begin{array}{l}\text { This study is considered the relationship between } \\
\text { volatility and predictability of profit }\end{array}$ \\
\hline Dabagh nasab, M. [12] & 2006 & $\begin{array}{l}\text { The impact of macro-financial variables on the price } \\
\text { index of Tehran Stock Exchange }\end{array}$ & $\begin{array}{l}\text { This study is done to find The impact of } \\
\text { macro-financial variables on the price index }\end{array}$ \\
\hline Aghaii, M.A., Mokhtarian, O. [2] & 2005 & $\begin{array}{l}\text { Review of accounting and auditing investors in the } \\
\text { Tehran Stock Exchange }\end{array}$ & $\begin{array}{l}\text { This study is managed to review accounting and } \\
\text { auditing investors can find the indicators }\end{array}$ \\
\hline Dechow, P. and Dichev, I. [4] & 2002 & The quality of accruals and earnings & $\begin{array}{l}\text { This research is focussed on profit elements and try } \\
\text { to find some important results on this relationship }\end{array}$ \\
\hline Kadkhodaii, H. [16] & 2002 & the impact of macroeconomic variables on stock index & $\begin{array}{l}\text { This study is focussed on macroeconomic variables } \\
\text { specially revenues }\end{array}$ \\
\hline Khaleghi Moghadam, A. [8] & 2000 & $\begin{array}{l}\text { Effect of publication of priority on the dividend yield } \\
\text { on the stock exchange banks }\end{array}$ & $\begin{array}{l}\text { This study is done to find some important results on } \\
\text { profit and DPS }\end{array}$ \\
\hline Azizi, A. [6] & 2000 & $\begin{array}{l}\text { the effect of fluctuations in macroeconomic indicators } \\
\text { on stock returns }\end{array}$ & $\begin{array}{l}\text { This research is focussed on macroeconomic } \\
\text { variables and volatility }\end{array}$ \\
\hline
\end{tabular}

\section{Research Aims}

The research objectives are as follows:

- Investors and financial analysts as one of the main criteria for assessing the profit tend to measure future profitability to hold or sell their shares to make decisions.

- Investors with forecasting profit compare and judge organization's activities. The difference in the prediction makes the allocation of resources to departments and business units.

- Potential investors by forecasting future cash flows and profits, to invest their own capital and resource allocation.

- The impact of volatility was investigated as a kind of profit behavior on short-term and long-term profit predictability in order to improve the profit forecasts.

\section{Research Questions}

- Is there the relationship between volatility and predictability of profits in the short-term and long-term?

- Is there the relationship between predictability and the level of profits in the short term and long term?

\section{Research Hypotheses}

- There is a relationship between volatility and predictability of profits in the short-term and long-term

- There is a relationship between predictability and the level of profits in the short-term and long-term 


\section{Sample and Population}

The study of causal correlation and statistical population for the purpose of applied research is an Iranian bank and the period covered by this study is 5years and the years 2009 till 2014.

\section{Research Data Collection}

This study is Cross-sectional after an event. In this study, to collect data from both library and survey methods are used. In the library, theoretical and research background have been collected. And also, in the survey step, the required data for gathering the organization's financial information are used its website and annual financial reports.

\section{Research Analysis Method}

Analysis is based on descriptive and inferential statistics are used software SPSS and Microsoft Excel.

\section{Definitions}

\subsection{Profit}

In this study, the net profit before tax divided by average total assets. Average total assets are equal to the average total assets at the end of the current period and the beginning of period.

\subsection{The Profit Stability}

Profit stability is durability and stability of profit. Short-term profit stability includes $\beta_{l}$ (independent variable coefficient) in model (1) and long-term profit stability include $\beta_{l}$ in each models (2) to (5). For example $\beta_{l}$ coefficient in model (5) shows consistent profit stability in five-year time horizon.

\subsection{The Profit Predictability}

The predictability is ability to predict future profits. The ability to forecast profits in the short term is the coefficient of determination adjusted model (1) and the ability to predict the long-term, including the coefficient of determination adjusted for each of the models (2) to (5). For example, the coefficient of determination adjusted model (5) show predictability of five-year time horizon predictability profit.

\subsection{The Profit Volatility}

Volatility of profit in year ' $t$ ' is the standard deviation of ' $t$ ' to' $t+4$ '. Clearly, the profits volatility determine the standard deviations of the fiscal year were identified and four of its previous financial year.

\subsection{Profit Forecast Error}

Profit forecast error is classified based on short-term and long-term forecast error. Short term forecast error is the difference between the actual profit and anticipated profit. Long-term profit forecast error is the difference between actual profit and the first anticipated profit that is announced from the date of financial statements publication up to a month after it $[1,3,6,10,15]$

\section{Research Model and Variables}

Research model is as follows:

1. $E t+1=\beta 0+\beta 1 E t+\varepsilon t$

2. $E t+2=\beta 0+\beta 1 E t+\varepsilon t$

3. $\mathrm{Et}+3=\beta 0+\beta 1 \mathrm{Et}+\varepsilon$

4. $E t+4=\beta 0+\beta 1 E t+\varepsilon t$

5. $E t+5=\beta 0+\beta 1 E t+\varepsilon t$

6. $\mathrm{EFt}+1=\beta 0+\beta 1$ High-volt $+\beta 2 \mathrm{EFt}+\beta 3$ High-volt* $\mathrm{EFt}+\varepsilon \mathrm{t}$

In this model, variables are:

$E_{t}$ : profit in year ' $\mathrm{t}$ '

$E_{t+1}$ : profit in year ' $\mathrm{t}+1$ '

$E_{t+2}$ : profit in year ' $\mathrm{t}+2$ '

$E_{t+3}$ : profit in year ' $\mathrm{t}+3$ '

$E_{t+4}$ : profit in year ' $\mathrm{t}+4$ '

$E_{t+5}$ : profit in year ' $\mathrm{t}+5$ '

High-vol : this is virtual variable. If it is volatile, is equal one and if the low volatility, is zero.

$E F_{t}$ : Short-term profit forecast error in year ' $\mathrm{t}$ '.

$E F_{t+1}$ : Short-term profit forecast error in year ' $\mathrm{t}+1$ '.

$\mathrm{High}_{\mathrm{vol}} * \mathrm{vF}_{t}$ : Variable interactions

$\varepsilon$ : Error correction

$\beta_{1}$ : Independent variable factor (coefficient)

Models (1) to (5), the models are sustainable profits and the data in year ' $t$ ' is the independent variable. Model (1) of short-term time horizon and models (2) to (5) long-term time horizons, respectively, two, three, four, five years are included. Model (6) is a tool to assess profit from forecasts.

\section{Describe the Data and Variables}

\subsection{The Basic Assumption of Regression}

In each regression model must make certain assumptions that if they violate from them, there are some problems about the desirability of the estimated regression parameters, or test of hypotheses. Regression basic assumptions are $[1,3,6,10$, 15]:

A) The average of $\varepsilon_{t}$ is equal to zero: due to randomness of $\varepsilon_{t}$, can be assumed to be written $E\left(\varepsilon_{t}\right)=0$, it Means that the constituent elements of the errors, put in place positive and negative effects that the average value of the error is zero.

B) The average of error variance totally is equal to fix digit same as $\sigma^{2}$. It means $V\left(\varepsilon_{T}\right)=\sigma^{2}$.

Assumptions A and B means that the distribution of errors should be normally distributed. So that the dispersion in the vicinity of the average, maximum, and the farther we get out on the right and left to a reduced rate. As a result, the distribution is bell shaped.

C) Error statements in observations are uncorrelated. If this 
assumption is violated, we will be faced with a problem called autocorrelation. In general, whenever $\varepsilon_{t}$ follow a certain discipline; it is violated assumption of uncorrelated $\varepsilon_{t}$ and there are positive or negative correlations, or a combination of positive and negative correlation.

D) Error statements are independent from independent variables: that is $\operatorname{cov}\left(X_{t} \varepsilon_{t}\right)=0$. In case of violation of this assumption, a detailed study of the effect of $\mathrm{x}$ on $\mathrm{y}$, as well as the impact of $\varepsilon_{t}$ on $X_{t}$ would not be possible.

E) The independent variable $X_{t}$, unlike the non-random variable $Y_{t}$.

F) The other assumption that it is just for multiple regression model is should increase the number of observations on the number of parameters and there is not linear relationship between the independent variables. This assumption is a necessary condition for achieving the results and estimated coefficients of multiple regression equations is normal. However, this assumption implies the absence of the full line.

G) The regression has to be linear.

\subsection{Statistical Tools}

Statistical tools employed are classified as follows:

1) Associated with regression testing.

2) Test the variables associated with the relationship.

3) Resampling.

\subsection{The Basic Hypothesis Testing of Regression}

A) Test of error normality same as Graphical method

B) Autocorrelation tests same as Durbin-Watson $\left(D W=\frac{\sum\left(e_{t}-e_{t-1}\right)^{2}}{\sum e_{t}^{2}}\right)$

C) Test multicollinearity same as Special values (Eigenvalue) and Status indicators

D) Test of the linear relationship between the dependent and independent variables same as variance analysis.

\subsection{Test Variables Associated with the Relationship}

A - The significance of the independent variable factor same as analysis of statistic ' $t$ '.
(B) States that hypothesis H0: $\beta_{1}=0$ in simple linear regression cannot be ruled out same as the scatter plot $\mathrm{x}, \mathrm{y}$ pairs.

(C) The coefficient of determination and adjusted coefficient of determination

\subsection{Resampling}

Resampling is a simple way but powerful method of sampling that is to determine the statistical accuracy or determine distribution of the test sample. Resampling is a sampling with replacement that comes from a sample obtained by the conversion. Or in other words resampling is a sampling with replacement in a special sample. Resampling method based on a sample of which is often the only source of the sample, a researcher for the study, and this adds to the importance of resampling. The principle of equality resampling say sampling estimated is equal to the estimate of the original sample $[3,15]$.

\section{Result and Discussion}

Descriptive statistics presented reflect the information on a central parameter (mean) and dispersion parameters (standard deviation, maximum and minimum) are variables. As Table 2 shows the median annual profit is positive and amount of maximum value is more than absolute of minimum.

Due to the volatility that is SD profit in five years, minimum volatility is positive. Median of annual profit is more than four seasons and eight seasons' fluctuations and this result indicates that changes throughout the year are more than during the season. Also, the annual number of variables is greater than seasonal fluctuations.

The reason of this failure is lack of full access to seasonal information. Because in the absence of information is one of the seasons of the year is not possible to calculate volatility. Because the eight seasonal fluctuations include two years (eight seasons), the number of eight seasonal fluctuations is less than four one. Another point is that the mean and median, the short-term and long-term profit, forecast error both negative and very close to zero while the absolute minimum is much more variable than their maximums. However, both variables forecast are optimistic.

Table 2. Research variables.

\begin{tabular}{|c|c|c|c|c|c|c|c|}
\hline maximum & median & minimum & stead deviation & mean & number & symbol & Variable \\
\hline 0.8112 & 0.118 & $0.4963-$ & 0.174 & 0.144 & 1100 & $E$ & annual profit \\
\hline 0.615 & 0.071 & 0.005 & 0.059 & 0.084 & 938 & $E V$ & annual profit volatility \\
\hline 0.676 & 0.019 & 0.002 & 0.062 & 0.034 & 298 & $E V_{4 q}$ & quarterly volatility \\
\hline 0.54 & 0.023 & 0.003 & 0.058 & 0.037 & 213 & $E V_{8 q}$ & eighthly volatility \\
\hline 1.832 & 0.168 & $0.26-$ & 0.18 & 0.206 & 470 & $F_{t}$ & short-term forecasting \\
\hline 2.415 & 0.143 & $0.136-$ & 0.163 & 0.171 & 674 & $F_{t+1}$ & long-term forecasting \\
\hline 0.276 & 0 & $1.73-$ & 0.106 & $0.004-$ & 470 & $E F_{t}$ & short-term forecasting error \\
\hline 0.573 & $0.001-$ & $2.457-$ & 0.152 & $0.005-$ & 674 & $E F_{t+1}$ & long-term forecasting error \\
\hline
\end{tabular}




\subsection{Test the First Hypothesis}

There is a relationship between volatility and predictability of profits in the short term and long term.

In this hypothesis, the relationship between volatility and the ability to forecast profits is discussed. For testing this hypothesis, profit volatility (total of 938 data) is classified into five classes of low volatile up to high.

In Table 3, annual sustainable model is implemented in total and for each class. Adjusted coefficient of determination is 0.631 and total stability coefficients for each class are likely to be significant (99\%). Errors independence test for all classes is (Durbin-Watson test) between 1.5 to 2.5. In other words, there was errors independence. Normal errors for all classes are established. Due to the significant level is smaller than test error of .05 , so, with 95 percent, it can be said that the profit predictability has a negative relationship with volatility profit. Table 3 is done based on annual sustainable model that is run for profit volatility. And the difference in adjusted coefficient of determination for low volatility and high is discussed with resampling and Statistics' $\mathrm{t}$ '.

Table 3. Test the first hypothesis $\left(E_{t+1}=\beta_{0}+\beta_{l} E_{t}+\mathcal{E}_{t}\right)$.

\begin{tabular}{|c|c|c|c|c|c|c|c|c|c|}
\hline $\begin{array}{l}\text { Durbin- } \\
\text { Watson }\end{array}$ & $\begin{array}{l}\text { Average resampling } \\
\text { adjusted coefficient of } \\
\text { determination }\end{array}$ & $\begin{array}{l}\text { Average } \\
\text { resampling } \\
\text { sustainability }\end{array}$ & $\begin{array}{l}\text { Adjusted coefficient } \\
\text { of determination } \\
\text { (R2) }\end{array}$ & P-value & $\begin{array}{l}\text { Sustainability } \\
\text { index ( } \beta 1)\end{array}$ & P-value & $\begin{array}{l}\text { Fix } \\
\text { index } \\
\left(\beta_{0}\right)\end{array}$ & Number & Cluster \\
\hline 1.878 & - & - & 0.631 & 0 & $\begin{array}{l}{ }^{* * *} 0.804 \\
-40.005\end{array}$ & 0.001 & $\begin{array}{l}{ }^{* *} 0.015 \\
-3.225\end{array}$ & 938 & total \\
\hline 1.951 & 0.624 & 0.919 & 0.622 & 0 & $\begin{array}{l}{ }^{* *} 0.917 \\
-17.556\end{array}$ & 0.699 & $\begin{array}{l}0.003 \\
-0.388\end{array}$ & 188 & $\begin{array}{l}\text { low } \\
\text { volatility }\end{array}$ \\
\hline 1.954 & - & - & 0.616 & 0 & $\begin{array}{l}{ }^{* *} 0.791 \\
-17.294\end{array}$ & 0.026 & $\begin{array}{l}{ }^{*} 0.02 \\
-2.237\end{array}$ & 187 & 2 \\
\hline 1.923 & - & - & 0.668 & 0 & $\begin{array}{l}{ }^{* *} 0.847 \\
-19.445\end{array}$ & 0.858 & $\begin{array}{l}0.002 \\
-0.179\end{array}$ & 188 & 3 \\
\hline 2.249 & - & - & 0.723 & 0 & $\begin{array}{l}{ }^{* *} 0.898 \\
-22.081\end{array}$ & 0.734 & $\begin{array}{l}0.003- \\
(0.34-)\end{array}$ & 187 & 4 \\
\hline 1.679 & 0.553 & 0.71 & 0.548 & 0 & $\begin{array}{l}{ }^{* *} 0.707 \\
-15.098\end{array}$ & 0.009 & $\begin{array}{l}{ }^{* *} 0.037 \\
-2.657\end{array}$ & 188 & $\begin{array}{l}\text { high } \\
\text { volatility }\end{array}$ \\
\hline & $\begin{array}{l}{ }^{* *} 0.071 \\
-27.471\end{array}$ & $\begin{array}{l}{ }^{* *} 0.209 \\
-74.954\end{array}$ & \multirow[t]{2}{*}{0.074} & & 0.21 & \multicolumn{4}{|c|}{ Difference between the low and high volatility } \\
\hline & 0 & 0 & & & & p-value & & & \\
\hline
\end{tabular}

(**) Significant error of $1 \%$ and $(*)$ significant error in 5\%. Numbers in parentheses are t-statistics.

In this study, the focus is on low levels of volatility and high. Because the property of profits predictability variable (the impossibility of using volatility variable and profits predictability in a model), classes with average volatility do not discuss in hypothesis tests. Rate stability and low adjusted coefficient of determination in class, respectively, 0.21 and 0.074 is more than high volatility class. In fact, low volatility has more steady stability and predictability than high volatility To test the differences is used resampling and the $t$ test with repeat of 1000 . Clearly, the annual stability model is done for low volatility and high for each class with 1000 times resampling to make 1000 times stability coefficients and adjusted coefficients of determination for each class. Resampling average of stability and adjusted determination coefficients in low-volatile and volatile classes is close to the coefficients obtained by the original sample. Average resampling of stability and adjusted determination of the coefficients in low class are respectively 0.209 and 0.071 more than high volatility, and each of these differences are significant with 95 percent. Due to the significant level is smaller than test error of 0.05 , thus, with probability of 95 percent, profit stability as well as profit predictability with profit volatility is negative relationship.

Totally, the first hypothesis states that the relationship between volatility and predictability of profits in the short term and long term.

\subsection{Test the Second Hypothesis}

There is a relationship between predictability and the level of profits in the short term and long term benefits. In table 4 and 5, Tests between predictability and the level of profits in the short-term and long-term are shown.

To review and approve additional findings about the profits predictability and level in short term and long term are calculated the averages and statistics ' $t$ ' of the current profit and it is done to predict in short term and long term and the difference between prediction and actual.

As can be seen in both short-term and long-term significance level is smaller than test error of $0.05 \mathrm{so}$, there is a relationship between profit predictability and level in the short and long term. 
Table 4. Test between predictability and the level of profits in the short-term.

\begin{tabular}{|c|c|c|c|c|c|c|c|c|c|c|}
\hline \multirow{2}{*}{ cluster } & \multicolumn{3}{|c|}{ Current actual profit } & \multicolumn{3}{|c|}{ Predict the long-term profit } & \multicolumn{3}{|c|}{ short-term actual profit } & \multirow{2}{*}{$\begin{array}{l}\text { Differences between } \\
\text { anticipated and } \\
\text { actual future profits }\end{array}$} \\
\hline & high & low & differences & high & low & differences & high & low & differences & \\
\hline number & 67 & 49 & - & 67 & 49 & - & 67 & 49 & - & - \\
\hline mean & 0.397 & 0.241 & ${ }^{* *} 0.156$ & 0.307 & 0.201 & ${ }^{* *} 0.106$ & 0.361 & 0.216 & ${ }^{* *} 0.145$ & $-0.04^{* *(1)}$ \\
\hline $\mathrm{t}$ & - & - & 6.099 & - & - & 5.36 & - & - & 4.786 & -39.412 \\
\hline p-value & - & - & 0 & - & - & 0 & - & - & 0 & 0 \\
\hline
\end{tabular}

(**) Significant error of $1 \%$

Table 5. Test between predictability and the level of profits in the long-term.

\begin{tabular}{|c|c|c|c|c|c|c|c|c|c|c|}
\hline \multirow{2}{*}{ cluster } & \multicolumn{3}{|c|}{ Current actual profit } & \multicolumn{3}{|c|}{ Predict the long-term profit } & \multicolumn{3}{|c|}{ short-term actual profit } & \multirow{2}{*}{$\begin{array}{l}\text { Differences between } \\
\text { anticipated and } \\
\text { actual future profits }\end{array}$} \\
\hline & high & low & differences & high & low & differences & high & low & differences & \\
\hline number & 46 & 13 & - & 46 & 13 & - & 46 & 13 & - & - \\
\hline $\mathrm{t}$ & - & - & 6.845 & - & - & 3.343 & - & - & 3.161 & -21.578 \\
\hline p-value & - & - & 0 & - & - & 0.002 & - & - & 0.003 & 0 \\
\hline
\end{tabular}

(**) Significant error of $5 \%$

\section{Conclusion}

The managers are trying to use a variety of resources and tools to achieve the best and most accurate profits prediction. Also, a lot of researches in the field of improving profit forecasts have been conducted by management.

In this study, the data from 2009 till 2014 are analyzed and calculates the quantitative variables such as volatility and forecasts and the calculation of prediction error and data analysis through software using both the hypothesis, and the end important and practical results have been achieved.

The results are shown that the volatility and predictability of profit in short-term and long-term have a negative relationship. As well as the profit volatility and profit level in short-term and long-term profit have a negative relationship.

Clearly, in little damping current profit is more appropriate description of the criteria for the future profits to the volatile situation.

This finding indicates that each of variables of current profit level and profit volatility of quarterly in long-term and short-term have strong relationship with predictability to the fluctuations of annual profits.

One of the behaviors of the phenomenon of mean reversion is positive relationship between the level of profit and the ability to forecast profits. In fact, the ability to forecast profits in the short-term and long-term profits is more than median profit.

\section{References}

[1] Taghavi, M. Janani, M.H. (2010), Tehran Stock Exchange and macroeconomic variables, Stock Exchange journal, No. 24, P. 16

[2] Aghaii, M.A., Mokhtarian, O. (2005), Review of accounting and auditing investors in the Tehran Stock Exchange, Stock Exchange journal, No. 36, P. 3-25
[3] Mehrani, S., Hesarzade, R. (2012), Fluctuations in its earnings forecasts, Journal of Accounting, year two, No. 6.

[4] Dechow, P. and Dichev, I. (2002). The quality of accruals andearnings: the role of ccruas in estimation errors. TheAccounting Review. 77: 35-59.

[5] Odean, T. (1998). Volume, volatility, price, and profit when all traders are above average. The Journal of Finance, 53(6), 1887-1934.

[6] Azizi, A. (2000), the effect of fluctuations in macroeconomic indicators on stock returns, MSc dissertation, Azad University, Tehran, Iran, department economy and managemenet

[7] Goncalves, S., \& Guidolin, M. (2006). Predictable dynamics in the S\&P 500 index options implied volatility surface. The Journal of Business, 79(3), 1591-1635.

[8] Khaleghi Moghadam, A. (2000), Effect of publication of priority on the dividend yield on the stock exchange banks, Quarterly Journal of humanities and social sciences, year 4, No. 15

[9] Manson, S. and Coakley, J. (2009). Does volatility improve UK earnings forecasts? Journal of Business Finance \& Accounting, 36 (9-10): 1148-1179.

[10] Dabagh nasab, M. (2006), The impact of macro-financial variables on the price index of Tehran Stock Exchange, MSc dissertation, Tehran university, Iran, department economy

[11] Marquering, W., \& Verbeek, M. (2004). The economic value of predicting stock index returns and volatility. Journal of Financial and Quantitative Analysis, 39(02), 407-429.

[12] Nam, K., Pyun, C. S., \& Arize, A. C. (2002). Asymmetric mean-reversion and contrarian profits: anst-garch approach. Journal of Empirical Finance, 9(5), 563-588.

[13] Dichev, I. and Tang, V. W. (2009). Earnings volatility and earnings predictability. Journal of Accounting and Economics. 47: 160-181.

[14] Dichev, I. D. and Tang, V. W. (2008). Matching and the changing properties of accounting earnings over the last 40 years. TheAccounting Review. 83: 1-36. 
[15] Haghighat, H., Mo’tamed, M. (2012), Relationship between profit and forecast volatility, Accounting progress of Shiraz University, year3, No. 2, P. 65-87.
[16] Kadkhodaii, H. (2002), the impact of macroeconomic variables on stock index, Abrar eghtesadi journal, No. 10, P. 10-15. 